Bangladesh J. Plant Taxon. 26(1): 1-12, 2019 (June)

(C) 2019 Bangladesh Association of Plant Taxonomists

\title{
COMPARATIVE MORPHOLOGY AND ANATOMY OF SEEDS OF SOME AETHIONEMA W.T. AITON (BRASSICACEAE) TAXA FROM TURKEY
}

\author{
Mehmet Cengiz KaraismailoğLu ${ }^{1}$ \\ Department of Biology, Faculty of Art and Science, Siirt University, Siirt, Turkey \\ Keywords: Aethionema; Anatomy; Morphology; Seed; Taxonomy; Turkey.
}

\begin{abstract}
Seed morphology and anatomy are taxonomically significant in Brassicaceae. The seed structures of Aethionema from Turkey, which include 12 taxa (Aethionema syriacum, A. froedinii, A. arabicum, A. eunomioides, A. fimbriatum, A. speciosum subsp. speciosum, A. speciosum subsp. compactum, A. saxatile, A. oppositifolium, A. iberideum, A. armenum, A. grandiflorum) were studied for knowing seed morphological and anatomical features with one-way analysis of variance, cluster analysis and principal component analysis. Seed size, shape and color were examined with stereomicroscopy. The surface patterns of seed were observed using Scanning Electron Microscopy (SEM). In addition, structure, and thicknesses of testa and endosperm were investigated anatomically. Thickness of testa and endosperm were of major significance to illustrate interspecific relations among the examined taxa.
\end{abstract}

\section{Introduction}

The Brassicaceae is one of the largest angiosperm families, including ca. 340 genera and 3350 species distributed throughout the world mainly in temperate regions of the Northern Hemisphere (Al-Shehbaz, 1986; Khalik and Maesen, 2002; Karaismailoğlu, 2017).

Taxonomically the genus Aethionema W.T. Aiton is problematic. Turkey is one of the centers of biodiversity and its number in outside Anatolia diminishes progressively (Davis, 1965; Pinar et al., 2007). In Turkey, the genus represented with 45 Aethionema species, 20 species of which are endemic to Turkey (Davis, 1965; Guner et al., 2012; Karaismailoğlu, 2018). The genus is extremely variable in habit, fruit and floral morphology, and chromosome number (Appel and Al-Shehbaz, 2003; Al-Shehbaz et al., 2006). In addition, genus has a widespread convergence in traditional characters used in taxonomy, especially in fruit (Mummenhoff et al., 1997). This factor cause some problems in classification of the genus from time to time; hence additional characters are needed in the classification of the genus.

Micromorphological features are taxonomically significant in the species delimitation (Brochmann, 1992; Pinar et al., 2007), in determining evolutionary relationships and solving taxonomic problems (Khalik and Maesen, 2002). Especially, the seed coat variation is very important in infrageneric classification. Structures of the epidermal cells are also good diagnostic characteristics for the lower taxonomical categories (Barthlott, 1981; Khalik and Maesen, 2002). Likewise, seed and fruit anatomical characters are also used in systematic in determination of the natural limits of the genera (Karaismailoğlu, 2015a). However, there are only few taxonomical works on seeds structure of Aethionema and they are limited to few characteristics (Pinar et al., 2007; Atceken et al., 2016). Hence, the aim of this work is to test potency morphological and anatomical characters of seeds of some Aethionema taxa and their use in the classification within the genus using multivariate analyses and principal component analysis.

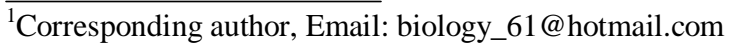




\section{Material and Methods}

The seeds of 12 taxa of Aethionema were utilized for the morphological and anatomical studies. The specimens were collected from natural populations and stored in SUFAF (Siirt University Fauna and Flora Center). 50 ripe seeds of each taxon were taken. All examined taxa are listed in Table 1 with their locations.

Table 1. The examined taxa and their locations.

\begin{tabular}{|c|c|c|}
\hline Taxa & Location & Voucher \\
\hline Aethionema syriacum & $\begin{array}{l}\text { Hatay, Dörtyol, Yahyalı plateau, meadows, } 750 \mathrm{~m} \text {, } \\
\text { 19.03.2017 }\end{array}$ & Karaismailoğlu 346 \\
\hline A. froedinii & $\begin{array}{l}\text { Gümüşhane, Kelkit, Akdağ, inclined slopes, } 2100 \text { m, } \\
\text { 09.07.2015 }\end{array}$ & Karaismailoğlu 213 \\
\hline A. arabicum & $\begin{array}{l}\text { Muğla, Köyceğiz, Ağla-Eren villages, roadsides, } 1753 \text { m, } \\
\text { 05.06.2015 }\end{array}$ & Karaismailoğlu 194 \\
\hline A. eunomioides & $\begin{array}{l}\text { Artvin, Yusufeli, Kılıçkaya, roadside, rocky slopes, } 704 \text { m, } \\
\text { 22.05.2015 }\end{array}$ & Karaismailoğlu 169 \\
\hline A. fimbriatum & Niğde, Çamardı, Yelatan village tops, 2083 m, 12.06.2016 & Karaismailoğlu 275 \\
\hline $\begin{array}{l}\text { A. speciosum subsp. } \\
\text { speciosum }\end{array}$ & $\begin{array}{l}\text { Artvin, Şavşat, Ciritdüzü village, stones slopes, } 1182 \text { m, } \\
\text { 10.07.2014 }\end{array}$ & Karaismailoğlu 67 \\
\hline $\begin{array}{l}\text { A. speciosum subsp. } \\
\text { compactum }\end{array}$ & $\begin{array}{l}\text { Muğla, Köyceğiz, Sandras mount, subalpin regions, slopes, } \\
1819 \text { m, 04.06.2016 }\end{array}$ & Karaismailoğlu 260 \\
\hline A. saxatile & Trabzon, Of, roadside, meadows, $10 \mathrm{~m}, 17.07 .2014$ & Karaismailoğlu 94 \\
\hline A. oppositifolium & $\begin{array}{l}\text { Ağr1, airport environments, open fields, meadows, } 1600 \text { m, } \\
\text { 16.05.2015 }\end{array}$ & Karaismailoğlu 164 \\
\hline A. iberideum & Erzurum, İspir-İkizdere, rocky slopes, 1154 m, 22.05.2015 & Karaismailoğlu 170 \\
\hline A. armenum & $\begin{array}{l}\text { Kahramanmaraş, Göksun, Berit mountain, humid areas, } \\
1750 \text { m, 19.06.2015 }\end{array}$ & Karaismailoğlu 206 \\
\hline A. grandiflorum & $\begin{array}{l}\text { Muğla, Marmaris, Kırzeytin mountain, serpentine stones, } \\
494 \mathrm{~m}, 05.06 .2015\end{array}$ & Karaismailoğlu 191 \\
\hline
\end{tabular}

Macromorphological features such as shape, size, and color of the seeds were studied using Olympus ZS51 stereomicroscope and Kameram Imaging Software. For micromorphological examinations of seed surface ornamentation, specimens were prepared for Scanning Electron Microscopy by mounting with silver adhesive on the stub, and gold coated, and examined with JEOL Neoscope-5000 Scanning Electron Microscope (Karaismailoğlu, 2015b).

The cross sections were taken from the middle part of the seed with an automatic microtome (Thermo Shonda Met Finesse). The specimens were placed in FAA for a minimum of $24 \mathrm{hrs,} \mathrm{then}$ dehydrated through ethanol and xylene series, and stained with hematoxylin (harris-RRSP67-E) in a dyeing apparatus (ASC 720 Medite), and were mounted with Entellan to observe anatomical features (Karaismailoğlu, 2015a, b). The anatomical characters (including testa and endosperm thicknesses) were observed and photographed with using Olympus CX21FS1 microscope and Kameram Imaging Software.

Data analyses presented in Tables 2 and 3 were made with Duncan's multiple-range test in SPSS computer program to determine the statistical significance of differentiations among the data to evaluate interspecific relationships (SPSS, 2006). Grouping of taxa was performed using the 


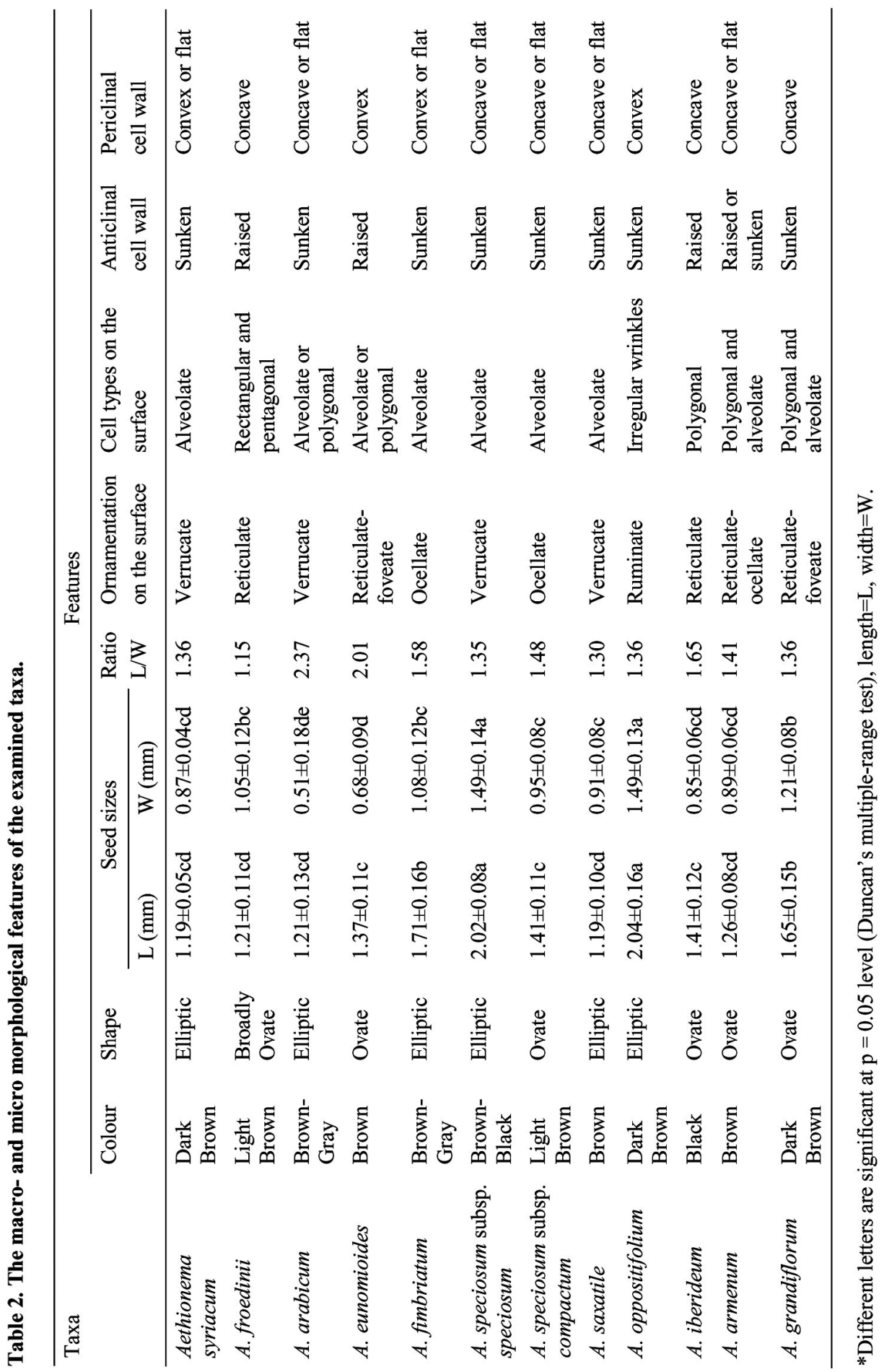




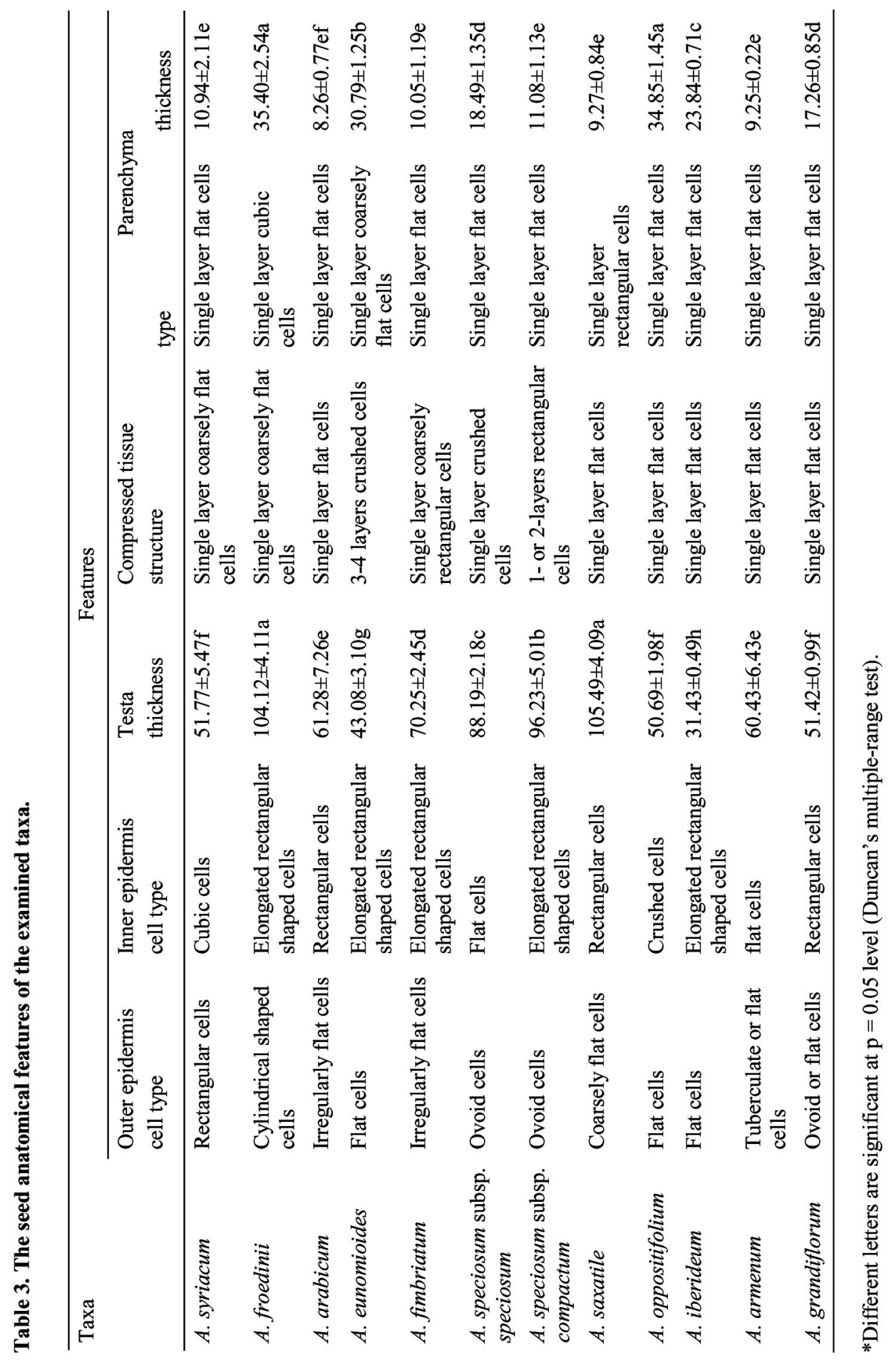


clustering analysis method (Unweighted Pair Group Method with Arithmetic mean, UPGMA) (Fig. 3). In addition, coordination and similarity matrix based upon Principal Component Analysis (PCA) were done (Fig. 4 and Table 3). All computations except Duncan's multiple range tests were performed by the MVSP software (Kovach, 2007).

\section{Results and Discussion}

Macro and micro morphological data on the seeds of the examined Aethionema taxa indicate a wide variation (Table 2). Color, shape, and size features of the examined taxa were studied macromorphologically. Seeds are elliptic (A. syriacum, A. arabicum, A. fimbriatum, A. speciosum subsp. speciosum, A. saxatile and A. oppositifolium) and ovate (A. eunomioides, A. speciosum subsp. compactum, A. iberideum, A. armenum and A. grandiflorum) or broadly ovate (A. froedinii) in shape and light Brown (A. froedinii and A. speciosum subsp compactum) or dark Brown (A. syriacum, A. oppositifolium and A. grandiflorum), Brown-Gray (A. arabicum and A. fimbriatum), Brown-Black (A. speciosum subsp. speciosum) and Black (A. iberideum) in color. Surface of the seeds is slightly rough or straight (Table 2). Seed sizes are variable, which range between 1.19 and $2.04 \mathrm{~mm}$ in length, and between 0.51 and $1.49 \mathrm{~mm}$ in width. Particularly, A. arabicum, A. speciosum subsp. speciosum and A. oppositifolium are of the greater variability among Aethionema taxa.

Seed surfaces of the taxa were examined as micromorphologically, and prominent characters such as surface ornamentations and cell types, periclinal and anticlinal cell walls of the seeds were recorded (Table 2 and Fig. 1). Six types of seed surface ornamentations were determined: verrucate in A. syriacum, A. arabicum, A. speciosum subsp. speciosum and A. saxatile, reticulate in A. froedinii and A. iberideum, reticulate-foveate in A. eunomioides and A. grandiflorum, ocellate in A. fimbriatum and A. speciosum subsp. compactum, ruminate in A. oppositifolium, and reticulate-ocellate in A. armenum. The most common type is verrucate, and, the least common types are ruminate and reticulate-ocellate (Table 2). This character is found to be taxonomically important in the delimitation of the taxa within the genus. Besides, cell shapes on the seed surfaces are very diverse, and consisted of alveolate cells, polygonal, rectangular, or pentagonal and irregular wrinkles. The predominant cell type is alveolate; the rare types are rectangular or pentagonal. At the same time, anticlinal cell walls in examined taxa are sunken or raised and flat or undulated, periclinal cell walls are convex, concave, and flat as well.

The outcomes of anatomical studies are given in Table 3 and Fig. 2. The testa epidermis in the examined taxa is scleranchymatic type and consists of two layers including outer and inner epidermis. The outer epidermis indicated markedly variations among the examined taxa. They are rectangular in A. syriacum, cylindrical in A. froedinii, flat in A. arabicum, A. eunomioides, A. fimbriatum, A. oppositifolium, A. iberideum, A. armenum and A. grandiflorum, ovoid in A. speciosum subsp. speciosum, A. speciosum subsp. compactum and A. grandiflorum, and tuberculate in A. armenum, waved or straight and thick or thin-walled, regular or irregular cells in the cross-sections (Fig. 2). However, the inner epidermis is in the form such as cubic in $A$. syriacum, rectangular in A. froedinii, A. arabicum, A. eunomioides, A. fimbriatum, A. speciosum subsp. compactum, A. saxatile, A. iberideum and A. grandiflorum, flat in A. speciosum subsp. speciosum and A. armenum, and crushed in A. oppositifolium. Besides, the mean values of the testa thickness range between $105.49 \mu \mathrm{m}$ and $31.43 \mu \mathrm{m}$. Accordingly, testa covers the most location in testa based on other examined anatomical characters. As well as, parenchyma (endosperm) cells in the examined taxa are single-layered and are composed of the flattest, rarely cubic, and rectangular cells. Endosperm thickness in examined taxa range between $35.40 \mu \mathrm{m}$ and $8.26 \mu \mathrm{m}$; the widest endosperm is noted in A. froedinii; however, it is the narrowest in $A$. arabicum (Table 3 ). 


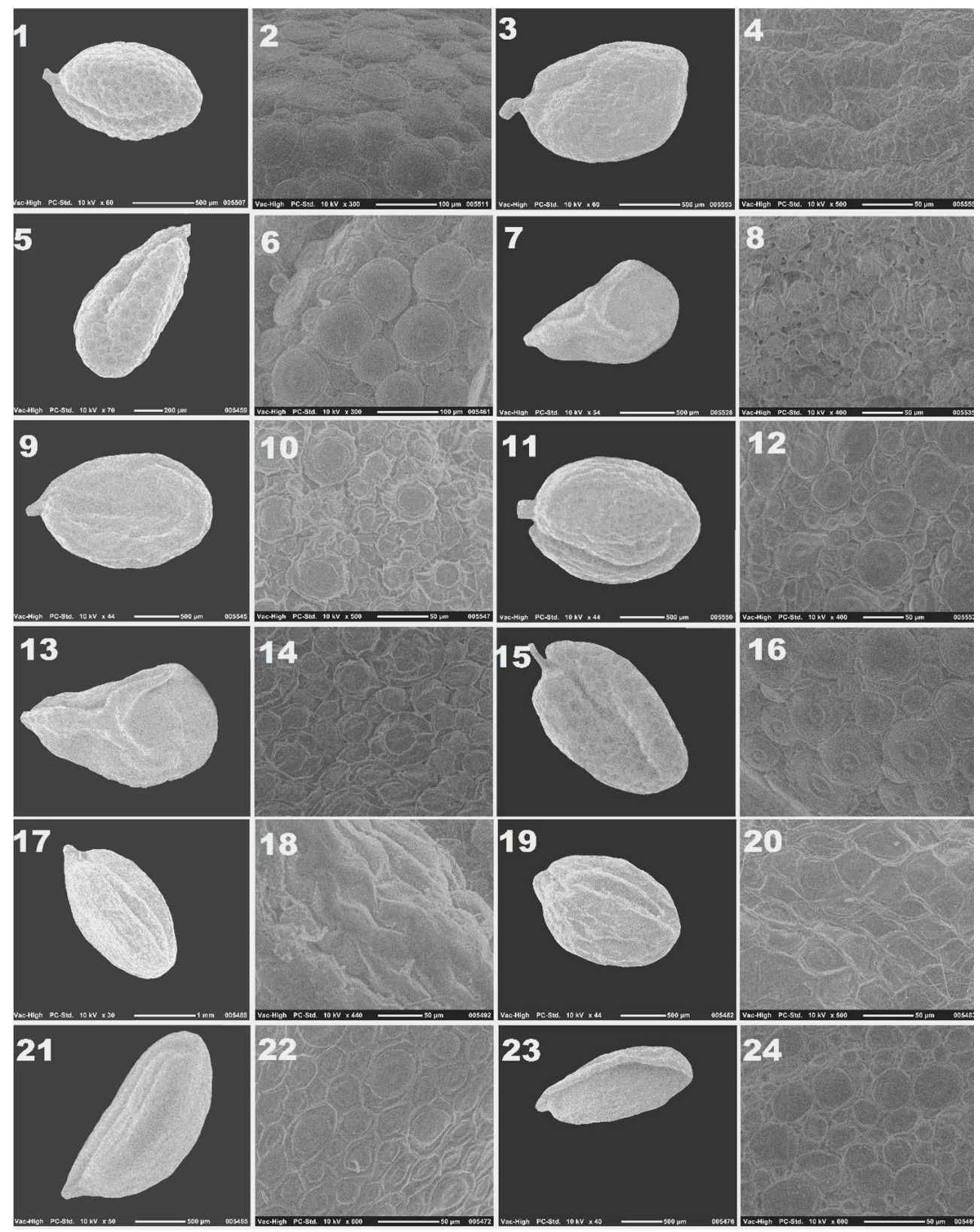

Fig. 1. SEM micrographs of the examined taxa: 1-2. A. syriacum, 3-4. A. froedinii, 5-6. A. arabicum, 7-8. A. eunomioides, 9-10. A. fimbriatum, 11-12. A. speciosum subsp. speciosum, 13-14. A. speciosum subsp. compactum, 15-16. A. saxatile, 17-18. A. oppositifolium, 19-20. A. iberideum, 21-22. A. armenum, 23-24. A. grandiflorum.

The UPGMA dissimilarity clustering dendrogram for the studied taxa is shown in Fig. 3. A. speciosum subsp. speciosum, A. speciosum subsp compactum, A. saxatile and A. froedinii form cluster A; other eight taxa form cluster B. In cluster A three taxa, A. speciosum subsp. speciosum, 
A. speciosum subsp. compactum and A. saxatile formed a subclade A, where A. froedinii is distantly related to them. Cluster B further formed two distinct subclades. B1 consists of $A$. iberideum, A. oppositifolium and A. eunomioides; B2 grouped A. fimbriatum, A. armenum, A. arabicum, $A$. grandiflorum and $A$. syriacum.

1

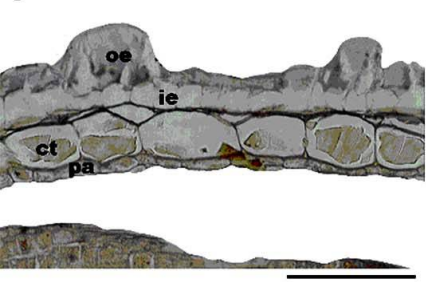

4

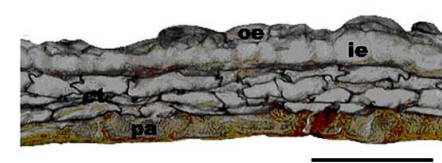

7

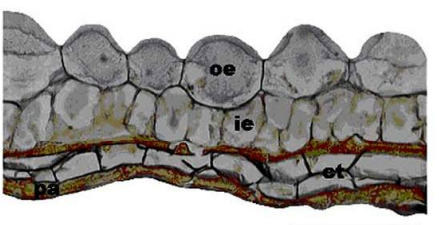

10

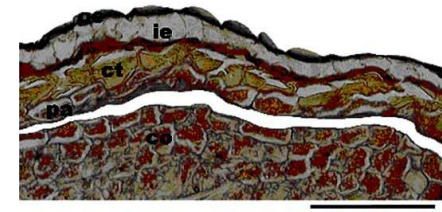

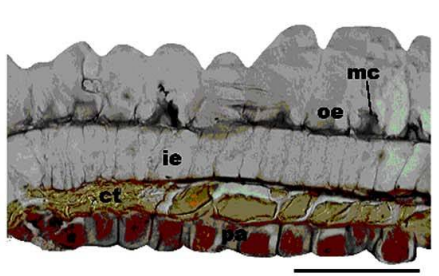

5

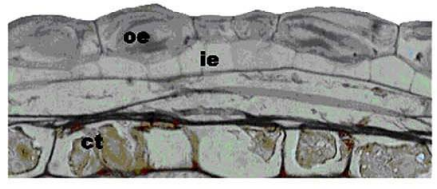

8

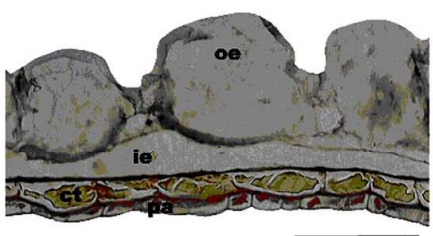

11

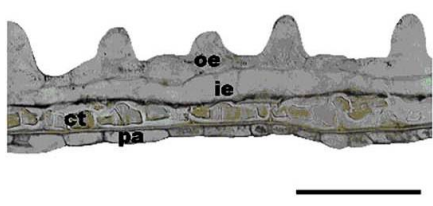

3

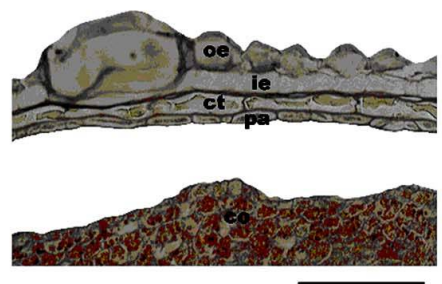

6

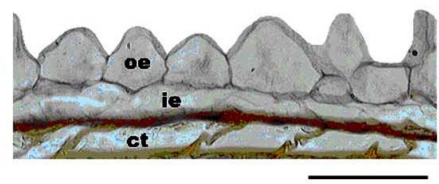

9

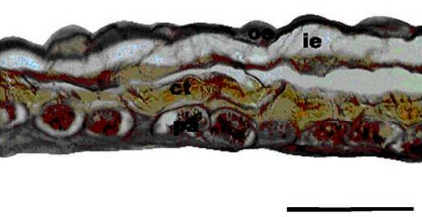

12

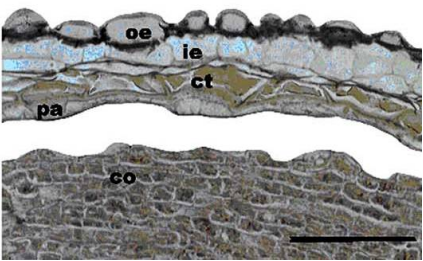

Fig. 2. The seed anatomical structures of the examined taxa; 1. A. syriacum, 2. A. froedinii, 3. A. arabicum, 4. A. eunomioides, 5. A. fimbriatum, 6. A. speciosum subsp. speciosum, 7. A. speciosum subsp. compactum, 8. A. saxatile, 9. A. oppositifolium, 10. A. iberideum, 11. A. armenum, 12. A. grandiflorum (oe: outer epidermis, ie: inner epidermis, ct: compressed tissue, pa: parenchyma, co: cotyledon, scale bars: $100 \mu \mathrm{m}$ ).

As shown in dendrogram, A. froedinii, A. iberideum and A. fimbriatum were prominently different from other taxa based on the examined characteristics (Table 2). The clades contained closely related taxa such as $A$. arabicum- $A$. armenum and $A$. syriacum- $A$. grandiflorum in compatible with the traditional taxonomic rank of Aethionema taxa in Turkey. It means that the macro and micro morphological and anatomical characteristics of the seeds are suitable with the used characters in the infra-generic separation of the Aethionema species in Flora of Turkey (Davis, 1965). 
PCA ordination and dissimilarity matrix in accordance with morphological and anatomical characters of seeds are given in Table 3 and in Fig. 4. The closest and the most distant taxa are determined. A. arabicum and A. armenum are the most closely related taxa (dissimilarity percentage: 1.15), as A. saxatile and A. iberideum are the most distant taxa (dissimilarity percentage: 19.56) (Table 4 and Fig. 4). In addition, the cumulative variance value of principal components achieved $59.41 \%$ (Axis 1: $39.23 \%$, Axis 2: $20.18 \%$ ).

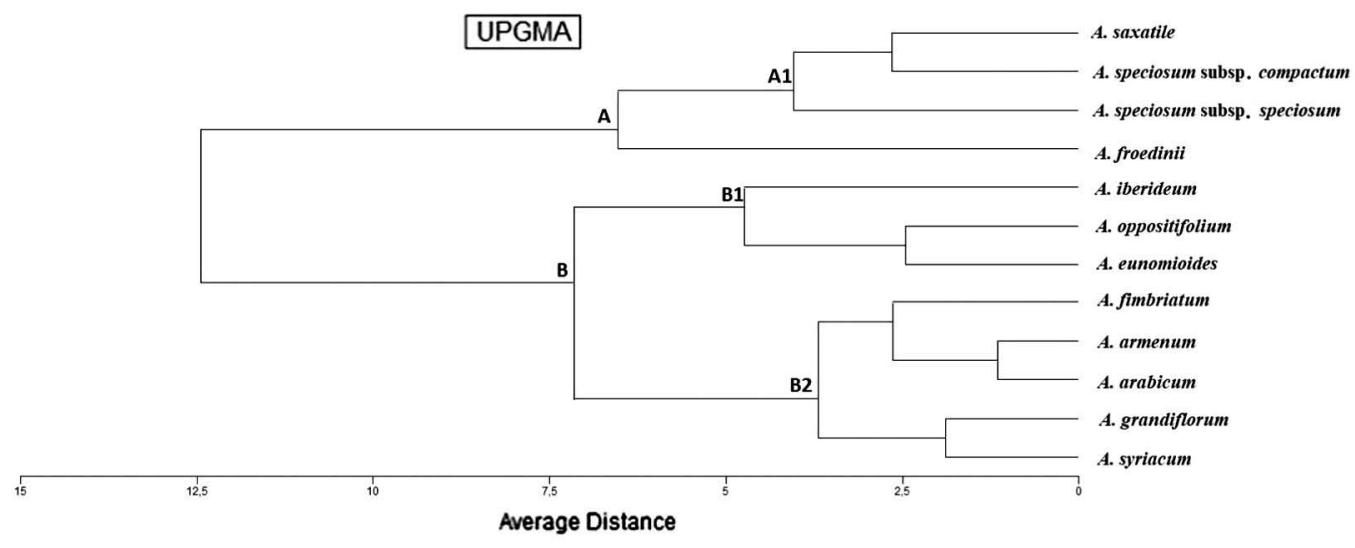

Fig. 3. UPGMA of the examined taxa.

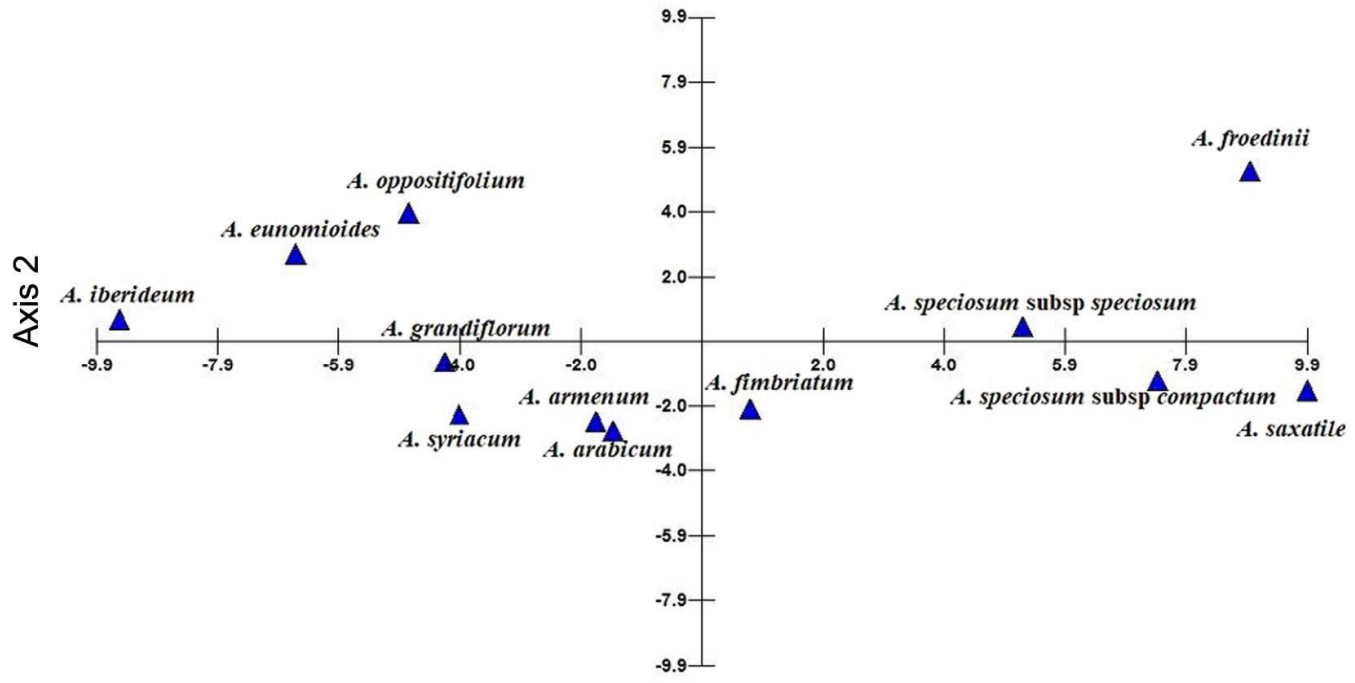

Axis 1

Fig. 4. Principal component analysis of the examined taxa. 


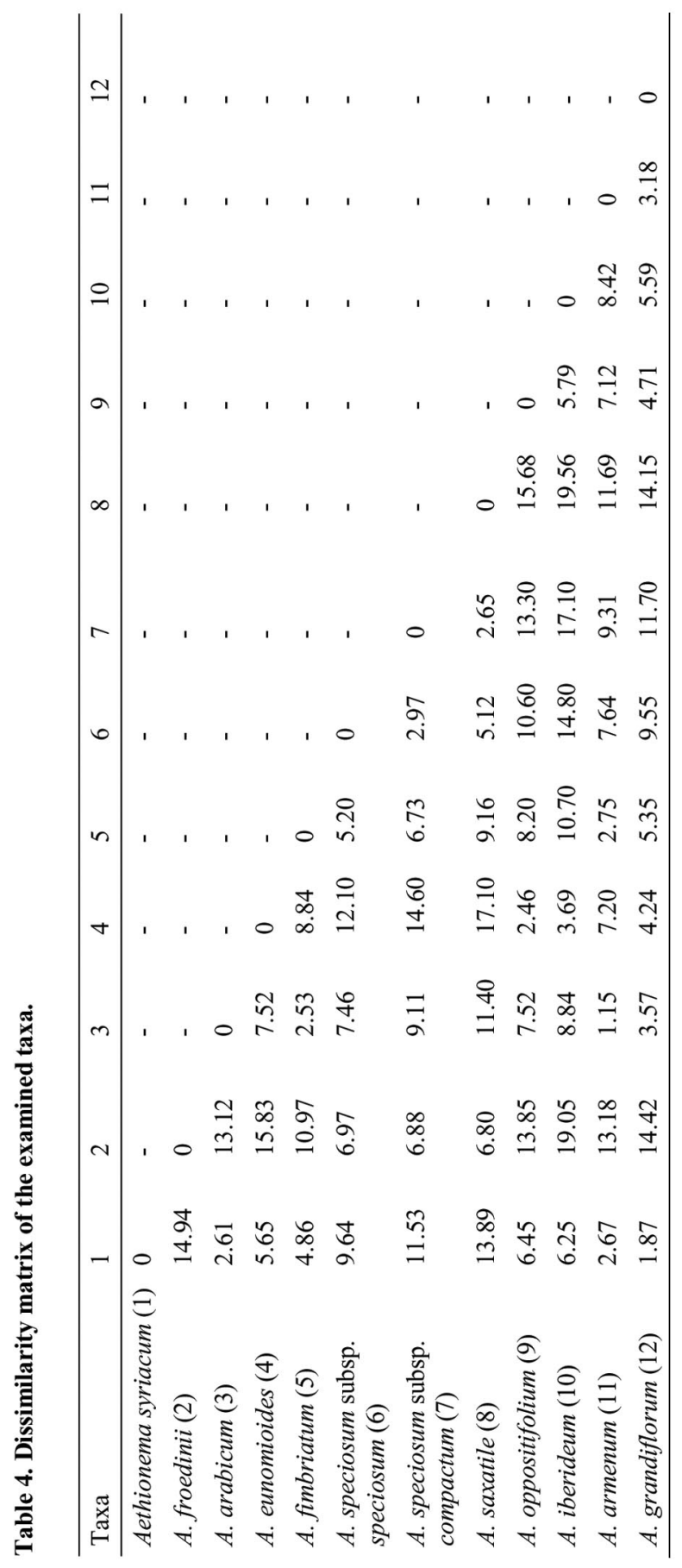


The classification of the Aethionema taxa is based on fruit morphology (Davis, 1965), however; the main differences in fruit morphology and the widespread convergence in this character within family drift into complexity systematics of genus in Turkey (Mummenhoff $e t$ al., 1997). To illuminate this problem, the morphological (macro and micro) and anatomical characters of the seeds, which are rarely referred to systematics of genus and no comprehensive researches have been performed so far, are used as an additional character in this study.

The morphological features of the seeds present valuable data in the evolutionary classification of flowering plants (Corner, 1976; Kaya et al., 2011). The seed morphology of the examined Aethionema taxa includes important information in the identification. The seed morphological variations have been found at the species level, especially in seed color and sizes. Seed color ranges from light brown, dark brown, brown-black to brown-grey (Table 2). Seed color is diagnostic at the generic and specific level for some extent. The information of seed color is consistent with some previous studies such as Barthlott (1984), Pinar et al. (2007, 2009), Kasem et al. (2011), Kaya et al. (2011) and Karaismailoğlu (2016). Also, the observed morphological variations in the seed are compatible with the diagnostic characters in Flora of Turkey (Davis, 1965) for Aethionema taxa.

Fruit or seed surface structure have been variously utilized for solving taxonomical problems, interpretation of evolutionary relationship and illumination of the adaptive characters of the fruit or seed surface (Sulaiman, 1995; Pinar et al., 2007; Karaismailoğlu, 2015a). Seed coat surface features such as surface ornamentation, anticlinal and periclinal cell wall patterns, and epidermal cell structure, have been found as helpful in delimitation of taxa within some genera in Brassicaceae family (Murley, 1951; Vaughan and Whitehouse, 1971; Barthlott, 1981; Koul et al., 2000; Moazzeni et al., 2007; Karaismailoğlu, 2016).

In this study, seed surface ornamentations, which are verruculate, reticulate, reticulatefoveate, ocellate, ruminate and reticulate-ocellate, can be served as good diagnostic characters at the specific level. The seed surface patterns in A. syriacum, A. froedinii, A. fimbriatum, A. speciosum subsp. speciosum, A. speciosum subsp. compactum, A. saxatile and A. oppositifolium taxa are reported here for the first time. This character found useful in separation of the following taxa, A. speciosum subsp. speciosum and A. grandiflorum taxa. Reticulate type is the most common surface ornamentation found among the taxa studied. It has commonly used in generic level in the family Brassicaceae (Barthlott, 1981; Koul et al., 2000; Zeng et al., 2004; Moazzeni et al., 2007; Karaismailoğlu, 2016).

The outcomes of this study are congruent with seed surface is reticulate or verrucate in Aethionema iberideum, A. eunomioides, A. arabicum and A. armenum (Pinar et al., 2007; Atceken et al., 2016). This paper is the first report to the ocellate seed surface ornamentations of $A$. speciosum subsp. compactum, and A. fimbriatum, ruminate ornamentation type for $A$. oppositifolium (Fig. 1). Seed surface ornamentation is reported as reticulate-verrucate (Pinar et al., 2007) and verrucate (Atceken et al., 2016) in A. armenum, while current investigation reports as reticulate-foveate. The unique morphological microcharacters have reflected a correlation between a molecular data and the morphological characters utilized in classification (Batur, 2014).

Characteristics of testa epiderma cells are taxonomically significant at the generic and subgeneric levels (Tegel, 2002; Karaismailoğlu, 2015a). These characteristics are found inconsistent in the present investigation. The outer epidermal cells are composed of rectangular, cylindrical, flat, ovoid, and tuberculate in forms with thick or thin wall. The inner epidermal cells are cubic, rectangular, flat, and crushed in forms as well. At the same time, the widest testa is noted in A. saxatile, whereas narrowest is in A. iberideum. Present investigation reveals that the testa epidermal features can be a helpful taxonomic character in separation of Aethionema taxa. 
Current results are compatible with previous studies such as Vaughan and Whitehouse (1971); Meyer (1973, 1979, 1991) and Moazzeni et al. (2007).

A dendrogram was created to evaluate the morphological and anatomical features of the seeds of the Aethionema taxa with UPGMA of cluster analysis. The morphological and anatomical characteristics of the seeds have supported the features utilized in the separation of Aethionema taxa of Turkey.

Principal component analysis may be helpful in providing information about the variability of the used characteristics. The obtained cumulative variance values of principal components indicate that the examined characteristics in Aethionema taxa may be utilized in explaining the differences among the taxa because of high variance value. Dissimilarity ratios among the taxa were determined. Accordingly, the closest relationship was seen between A. arabicum and A. armenum, however, the most distant relationship was found between A. saxatile and A. iberideum.

In the present study, significance of some characteristics in the infrageneric delimitation in Aethionema has been examined. The application of some seed characters, which are generally related with seed micromorphological and anatomical patterns, can be useful in the systematics of genus, and supportive ancestral characters in the infra generic classification. This is a preliminary investigation of systematic significance of some seed morphological and anatomical characteristics of the genus Aethionema; further extensive studies including all taxa of the genus would be helpful in better understanding systematic problems of the genus Aethionema.

\section{Acknowledgements}

The author thanks the professors in Istanbul University, Division of Botany for providing the facilities of some equipments.

\section{References}

Al-Shehbaz, I.A. 1986. The genera of Lepidieae (Cruciferae; Brassicaceae) in the Southeastern United States. J. Arnold. Arbor. 67: 265-311.

Al-Shehbaz, I.A., Beilstein, M.A. and Kellogg, E.A. 2006. Systematics and phylogeny of the Brassicaceae (Cruciferae): an overview. Pl. Syst. Evol. 259: 89-120.

Appel, O. and Al-Shehbaz, I.A. 2003. Cruciferae. In: Kubitzki, K. (Ed.), Families and Genera of Vascular Plants, Vol. 5. Springer, Berlin-Heidelberg, pp. 75-174.

Atceken, M.M., Dural, H. and Yilmaz Citak, B. 2016. The morphological, anatomical and palynological investigations on some taxa of genus Aethionema W. T. Aiton (Brassicaceae). Biodicon 9: 55-68.

Barthlott, W. 1981. Epidermal and seed surface characters of plants: systematic applicability and some evolutionary aspects. Nord. J. Bot. 1: 345-355.

Barthlott, W. 1984. Microstructural features of seed surface. In: Heywood, V.H. and D.C. Moore (Eds). Current Concepts in Plant Taxonomy. Academic Press, London, England, pp. 95-105.

Batur, O.S. 2014. Aethionema W.T. Aiton (Brassicaceae) cinsinin moleküler filogenisi. MSc thesis, Hacettepe university, Turkey.

Brochmann, C. 1992. Pollen and seed anatomy of Nordic Draba (Brassicaceae): phylogenetic and ecological implications. Nord. J. Bot. 12: 657-673.

Corner, E.J. 1976. The Seeds of Dicotyledons. 2 Vol. Cambridge University Press, England, pp. 35.

Davis, P.H. 1965. Flora of Turkey and the East Aegean Islands, Vol. 1. Edinburgh Univ Press, pp. 314-330.

Guner, A., Aslan, S., Ekim, T., Vural, M. and Babac, M.T. 2012. Türkiye bitkileri listesi (damarlı bitkiler). [A Checklist of the Flora of Turkey (Vascular Plants)]. Nezahat Gokyigit Botanik Bahcesi ve Flora Arastırmaları Dernegi Yayını, İstanbul, Türkiye, pp. 246-250. 
Karaismailoğlu, M.C. 2015a. Morphological and anatomical features of cypsela of some Crepis taxa (Asteraceae) from Turkey and their taxonomic importance. Pak. J. Bot. 47: 1473-1480.

Karaismailoğlu, M.C. 2015b. Morphological and anatomical features of seeds of Turkish Romulea taxa (Iridaceae) and their taxonomic significance. Acta Bot. Croat. 74: 31-41.

Karaismailoğlu, M.C. 2016. Addition to characters of endemic Aubrieta canescens subsp. canescens Bornm. (Brassicaceae) ,from Turkey. Bangladesh J. Bot. 45: 509-515.

Karaismailoğlu, M.C. 2017. Palynological features of eleven Aethionema taxa from Turkey and their systematic implications. Bangladesh J. Plant Taxon. 24: 197-204.

Karaismailoğlu, M.C. 2018. Seed mucilage content in Aethionema W.T. Aiton species and their significance in systematic and ecological aspects. Bangladesh J. Bot. 47: 445-449.

Kasem, W.T., Ghareeb, A. and Marwa, E. 2011. Seed morphology and seed coat sculpturing of 32 taxa of family Brassicaceae. J. Am. Sci. 7: 166-178.

Kaya, A., Ünal, M., Özgökçe, F., Doğan, B. and Martin, E. 2011. Fruit and seed morphology of six species previously placed in Malcolmia (Brassicaceae) in Turkey and their taxonomic value. Turk. J. Bot. 35: $653-662$.

Khalik, K. and Maesen Van Der, L.J.G. 2002. Seed morphology of some tribes of Brassicaceae (Implication for taxonomy and species identification for the flora of Egypt). Blumea 47: 363-383.

Koul, K.K., Nagpal, R. and Raina, S.N. 2000. Seed coat microsculpturing in Brassica and allied genera (Subtribe Brassicinae, Raphaninae, Moricandiinae). Ann. Bot. 86: 385-397.

Kovach, W.L. 2007. MVSP - A Multi Variate Statistical Package for Windows, ver. 3.1. Kovach Computing Services, Pentraeth, Wales, U.K.

Meyer, F.K. 1973. Conspectus der "Thlaspi" - Arten Europas, Afrikas und Vorderasiens. Feddes Repert. 84: 449-470.

Meyer, F.K. 1979. Kritische Revision der "Thlaspi" - Arten Europas, Afrikas und Vordersaiens I. Geschichte, Morphologie und Chorologie. Feddes Repert. 90: 129-154.

Meyer, F.K. 1991. Seedcoat anatomy as a character for a new classification of Thlaspi. Fl. Veg. Mundi. 9: 915.

Moazzeni, H., Zarre, S., Al-Shehbaz, I.A. and Mummenhoff, K. 2007. Seed coat microsculpturing and its systematic application in Isatis (Brassicaceae) and allied genera in Iran. Flora 202: 447-454.

Mummenhoff, K., Franzke, K.A. and Koch, M. 1997. Molecular data reveal convergence in fruit characters used in the classification of Thlaspi s.l. (Brassicaceae). Bot. J. Linn. Soc. 125: 183-199.

Murley, M.R. 1951. Seeds of the Cruciferae of North Eastern America. American Middle Naturalichen 46: $1-8$.

Pinar, N.M., Bayrak, N. and Geven, F. 2007. Seed coat macro sculpturing in some Turkish Aethionema R. Br. (Brassicaceae). Pak. J. Bot. 39: 1025-1036.

Pinar, N.M., Duran, A., Ceter, T. and Tug, G.N. 2009. Pollen and Seed Morphology of the Genus Hesperis L. (Brassicaceae) in Turkey. Turk. J. Bot. 33: 83-96.

SPSS Inc, 2006. SPSS Base 15.0 for windows, Chicago.

Sulaiman, I.M. 1995. Scanning electron microscopic studies seed coat patterns of five endangered Himalayan species of Meconopsis (Papaveraceae). Ann. Bot. 76: 323-376.

Tegel, F. 2002. Die Testa epidermis der Lactuaceae (Asteraceae) - ihre Diversitat und systematische Bedeutung. Ludwigs Maximillians. Munich.

Vaughan, J.G. and Whitehouse, J.M. 1971. Seed structure and the taxonomy of Cruciferae. Bot. J. Linn. Soc. 64: 383-409.

Zeng, C.H.L., Wang, J.B., Liu, A.H. and Wu, XM. 2004. Seed coat microsculpturing changes during seed development in diploid and amphidiploid Brassica species. Ann. Bot. 93: 555-566.

(Manuscript received on 14 March 2018, revised on 1 November 2018) 